\title{
Perubahan Perilaku Dormansi Selama Proses Desikasi pada Benih Kacang Bambara (Vigna subterranea L. Verdc.)
}

\section{Changes in Dormancy Behaviour During the Desiccation Process of Bambara Groundnut (Vigna subterranea L. Verdc.) Seeds}

\author{
Maryati Sari $^{1,2}$, Satriyas Ilyas ${ }^{2 *}$, M. Rahmad Suhartanto ${ }^{2}$, dan Abdul Qadir ${ }^{2}$ \\ 'Program Studi Ilmu dan Teknologi Benih, Sekolah Pascasarjana, Institut Pertanian Bogor \\ ${ }^{2}$ Departemen Agronomi dan Hortikultura, Fakultas Pertanian, Institut Pertanian Bogor \\ (Bogor Agricultural University), Jl. Meranti, Kampus IPB Darmaga, Bogor 16680, Indonesia
}

Diterima 29 Januari 2020/Disetujui 20 April 2020

\begin{abstract}
Bambara groundnut seeds often show unsynchronized and slow germination even though on newly harvested seeds. This might be due to the presence of seed dormancy. Therefore, the objective of this research was to obtain the information on seed dormancy and germination behaviour of bambara groundnut seeds during desiccation. The experiment was arranged in a nested design. Dormancy breaking treatments (untreated, mechanical scarification, soaking in $1 \% \mathrm{KNO}_{3}$ for 2 hours, mechanical scarification followed by $\mathrm{KNO}_{3}$ soaking) were nested in each of the desiccation levels (fresh seeds with 54.7\% moisture content (mc), desiccated seeds with $44.4 \%, 18.0 \%, 15.4 \%$, and $12.1 \% \mathrm{mc}$ ). The results showed that newly harvested seeds were in dormant state. Seed desiccation did not increase the intensity of seed dormancy, even resulted in an increase in field emergence (at 30 days after planting) from $43.9 \%$ in fresh seeds to around $70 \%$ in dry seed $(12-15 \% \mathrm{mc}$ ). Seed desiccation (from $44.4 \% \mathrm{mc}$ to $12.1 \% \mathrm{mc}$ ) increased the field emergence, although it was inadequate to break the dormancy completely. Meanwhile, seed desiccation tended to increase the GA/ABA ratio, but the seed permeability was decreased. The fact showed that seed desiccation reduced the intensity of dormancy of bambara groundnut seed, therefore, it is suggested to modify the drying method in order to accelerate the increasing of GA/ABA ratio while keeping the testa permeable.
\end{abstract}

Keywords: after-ripening, GA/ABA ratio, hard seed, kacang bogor, permeability

\section{ABSTRAK}

Benih kacang bambara seringkali menunjukkan perkecambahan yang lambat dan tidak serempak, bahkan pada benih yang baru dipanen. Hal ini kemungkinan disebabkan oleh dormansi benih. Oleh karena itu, penelitian ini bertujuan untuk memperoleh informasi perilaku dormansi dan perkecambahan benih kacang bambara selama proses desikasi. Percobaan disusun dalam rancangan petak tersarang. Perlakuan pematahan dormansi (kontrol, skarifikasi mekanik, perendaman dalam $\mathrm{KNO}_{3} 1 \%$ selama 2 jam, dan skarifikasi mekanik diikuti perendaman dalam $\mathrm{KNO}_{3}$ ) tersarang pada tingkat desikasi benih (benih segar dengan kadar air (KA) 54.7\%, benih dengan desikasi hingga KA 44.4\%, 18.0\%, 15.4\%, dan 12.1\%). Hasil penelitian menunjukkan benih kacang bambara yang baru dipanen berada dalam keadaan dorman. Desikasi pada benih tidak meningkatkan intensitas dormansi, bahkan meningkatkan daya tumbuh (pada 30 hari setelah tanam) dari 43.9\% pada benih segar menjadi sekitar 70\% pada benih kering dengan kadar air 12-15\%. Desikasi benih dari KA 44.4\% hingga 12.1\% meningkatkan daya tumbuh, meskipun tidak cukup untuk mematahkan dormansi. Sementara itu, desikasi juga cenderung meningkatkan rasio GA/ABA, namun mengakibatkan permeabilitas testa berkurang. Fakta menunjukkan desikasi mengurangi intensitas dormansi benih kacang bambara sehingga disarankan untuk melakukan modifikasi metode pengeringan untuk mempercepat peningkatan rasio GA/ABA dengan menjaga testa tetap permeabel.

Kata kunci: after-ripening, kacang bogor, kulit keras, permeabilitas, rasio GA/ABA

\footnotetext{
* Penulis untuk korespondensi. e-mail: satriyas252@gmail.com
} 


\section{PENDAHULUAN}

Kacang bambara (kacang bogor) merupakan underutilized crops yang dimanfaatkan baik sebagai tanaman hortikultura maupun sumber pangan pokok alternatif. Kandungan gizi kacang bambara meliputi karbohidrat $68.0 \%$, protein $17.7 \%$, lemak $6.6 \%$, serat $3.5 \%$, abu $4.2 \%$ (Abu-Salem dan Abou-Arab 2011), juga mengandung kalsium, besi, zink, magnesium dan mangan (Adelanwa et al., 2017), serta berpotensi sebagai tanaman tahan cekaman kekeringan (Mayes et al., 2019). Potensi hasil kacang bambara cukup baik, mencapai 11.5 ton polong segar ha' untuk kultivar lokal Lembang di Kalimantan Selatan (Adhi dan Wahyudi, 2018) dan 20.0-22.5 ton polong segar ha-1 untuk beberapa galur harapan (Bakti et al., 2018).

Permasalahan yang masih dihadapi saat ini adalah keterbatasan ketersediaan benih bermutu. Benih yang tersedia pun tidak selalu mampu berkecambah dengan baik, bahkan pada benih yang masih baru. Rendahnya perkecambahan pada benih yang masih baru biasa disebabkan oleh dormansi. Dormansi merupakan kondisi ketika benih hidup tidak mampu berkecambah meskipun kondisi lingkungan mendukung bagi perkecambahan. Dormansi pada benih kacang bambara telah dilaporkan keberadaannya oleh Miya dan Modi (2017). Dormansi pada benih sebenarnya bermanfaat secara ekologi untuk mempertahankan kelestarian spesies. Dormansi juga bermanfaat dalam praktik budidaya untuk mencegah perkecambahan sebelum panen (Mizuno et al., 2018), karena perkecambahan sebelum panen dapat menurunkan mutu produk pangan (Olaerts dan Courtin, 2018) dan juga merusak mutu benih (Shon et al., 2014). Namun demikian, dormansi perlu diatasi karena benih dorman tumbuh lambat dan tidak serempak, menghasilkan pertanaman yang lemah dan menyulitkan praktik budidaya.

Miya dan Modi (2017) mengemukakan bahwa dormansi pada benih kacang bambara merupakan dormansi fisik akibat kulit keras. Hal ini didukung penelitian Olaleye et al. (2013) tentang lignin yang terkonsentrasi pada testa benih kacang bambara dan menurut Ran et al. (2015) kandungan lignin yang semakin tinggi berkorelasi dengan testa yang semakin tebal.

Jenis dormansi lain yang seringkali terdapat pada benih adalah dormansi after-ripening. Kebiasaan petani menunda penggunaan benih yang masih baru untuk mendapatkan hasil perkecambahan yang lebih baik memunculkan dugaan adanya dormansi after-ripening pada benih kacang bambara. Informasi terkait faktor penyebab dormansi dan faktor yang mempengaruhinya perlu diketahui secara pasti, sehingga benih mendapatkan perlakuan yang tepat untuk mengatasi masalah dormansi.

Airmemegang peran penting pada benih. Berkurangnya kandungan air (desikasi) pada benih dapat mempengaruhi kondisi fisik (Jaganathan et al., 2017) maupun fisiologi benih (Oba et al., 2019). Kondisi fisiologi yang dapat mempengaruhi perkecambahan dan dormansi diantaranya adalah keberadaan fitohormon, khususnya giberelin (GA) dan asam absisat (ABA). Sementara itu, kondisi fisik yang banyak berpengaruh terhadap perkecambahan dan dormansi adalah kulit benih (testa). Perubahan GA, ABA dan permeabilitas testa diamati untuk mempelajari pengaruh desikasi terhadap dormansi. Informasi mengenai pengaruh desikasi terhadap dormansi sangat penting karena bermanfaat untuk menentukan metode penanganan benih secara tepat.

Penelitian ini bertujuan memperoleh informasi perilaku perkecambahan dan dormansi benih kacang bambara dari berbagai tingkat desikasi dan mendapatkan metode pematahannya.

\section{BAHAN DAN METODE}

Percobaan dilakukan pada benih kacang bambara lanras Sumedang. Benih lanras Sumedang yang digunakan diperoleh dari Kebun Kampung Manggis, Dramaga, Bogor (192 m dpl) yang ditanam pada Februari-Juni 2018. Kriteria benih bahan penelitian adalah benih sehat dan masak fisiologi (polong mengeras, warna polong lebih gelap dan tampak guratan, biji mulai mengeras dan bernas). Percobaan disusun dalam rancangan petak tersarang. Perlakuan pematahan dormansi tersarang pada tingkat desikasi. Tingkat desikasi benih meliputi: benih segar (kadar air 54.7\%, D0), benih dengan perlakuan desikasi hingga kadar air 44.4\% (D1), 18.0\% (D2), 15.4\% (D3), dan 12.1\% (D4). Perlakuan pematahan dormansi meliputi kontrol (P1), skarifikasi mekanik (P2), perendaman dalam $\mathrm{KNO}_{3} 1 \%$ selama 2 jam (P3), dan skarifikasi mekanik diikuti perendaman dalam $\mathrm{KNO}_{3}$ 1\% selama 2 jam (P4). Percobaan dilakukan sebanyak tiga ulangan.

Benih yang telah dipanen segera dikeringkan di dalam polongnya menggunakan batch-dryer suhu $35-40{ }^{\circ} \mathrm{C}$ hingga diperoleh kadar air sesuai perlakuan tingkat desikasi. Skarifikasi mekanik dilakukan dengan membuang sebagian testa menggunakan amplas (pada benih dengan KA $\leq 18 \%$ ) atau menggunakan cutter (pada benih dengan KA $>40 \%$ ) dengan diameter 3-5 mm pada posisi jauh dari hilum. Perendaman dalam $\mathrm{KNO}_{3} 1 \%$ dilakukan selama 2 jam pada kondisi terang dengan suhu kamar $\left(27-29^{\circ} \mathrm{C}\right)$.

Pengamatan terhadap laju imbibisi, kandungan $\mathrm{GA}_{3}$ dan ABA endogen dilakukan pada setiap tingkat kadar air benih. Pengamatan terhadap kadar air dan daya tumbuh benih di lapangan dilakukan pada setiap perlakuan pematahan dormansi pada setiap tingkat kadar air.

Kandungan asam giberelin $\left(\mathrm{GA}_{3}\right)$ dan asam absisat (ABA) diukur pada benih tanpa testa $( \pm 20$ g per sampel). Analisis dilakukan dengan metode HPLC di Laboratorium Bioteknologi, Puspiptek, LIPI. Laju imbibisi diukur berdasarkan peningkatan kandungan air akibat perendaman benih dalam air destilata pada suhu kamar $\left(25^{\circ} \mathrm{C}\right)$. Kurva imbibisi disajikan berdasarkan pengamatan periodik setiap 1 jam selama 6 jam. Setiap sampel menggunakan $\pm 10 \mathrm{~g}$ benih dalam $100 \mathrm{~mL}$ air destilata. Kadar air benih diukur dengan metode pemanasan pada suhu $103 \pm 2{ }^{\circ} \mathrm{C}$ selama $17 \pm 1$ jam dan dihitung berdasarkan bobot basah benih. Bobot per sampel \pm 5 g. Pengukuran laju imbibisi dan kadar air benih dilakukan di Laboratorium Ilmu dan Teknologi Benih, IPB. 
Daya tumbuh diuji di kebun Kampung Manggis, Dramaga, Bogor yang memiliki jenis tanah Latosol dengan rata-rata curah hujan bulanan $152.4 \mathrm{~mm}$. Pengujian dilakukan pada setiap kombinasi perlakuan dengan jumlah benih 30 butir per sampel. Persentase perkecambahan di lapangan dengan kriteria tunas telah muncul ke permukaan tanah dan plumula terbuka, diamati untuk mengetahui daya tumbuh benih hingga 30 hari setelah tanam (HST).

Data dianalisis dengan uji F. Analisis data dilanjutkan dengan DMRT taraf 5\% apabila perlakuan menunjukkan pengaruh yang nyata pada tingkat kepercayaan 95\%. Laju imbibisi benih dan persentase muncul kecambah di lapangan pada benih tanpa perlakuan pematahan dormansi dianalisis secara deskriptif.

\section{HASIL DAN PEMBAHASAN}

\section{Pengaruh Desikasi terhadap Daya Tumbuh Benih di Lapangan}

Benih segar tanpa desikasi memiliki kadar air 54.7\% (D0), benih yang telah mengalami desikasi berturutturut adalah desikasi hingga kadar air 44.4\% (D1), 18.0\% (D2), 15.4\% (D3), dan 12.1\% (D4). Berdasarkan standar pengujian daya berkecambah, viabilitas benih kacang bambara seharusnya dapat dievaluasi pada 10 HST atau dapat diperpanjang hingga 15 HST, baik pada pengujian di media kertas maupun pasir (ISTA, 2014). Pengamatan di lapangan yang dilakukan oleh Manggung et al. (2016) pada benih kacang bambara lanras Sumedang menunjukkan benih hanya memerlukan waktu 9.7 hari untuk berkecambah. Hal tersebut mendasari keyakinan adanya dormansi pada benih kacang bambara lanras Sumedang pada percobaan kali ini, yaitu pada benih yang baru dipanen. Hasil pengamatan menunjukkan hingga 15 HST belum satu pun benih yang mampu berkecambah, meskipun benih belum mati. Perkecambahan baru mulai muncul di lapangan pada 18 HST dan daya tumbuh di lapangan pada 30 HST berkisar antara $48.9 \%-82.2 \%$, dengan laju perkecambahan yang bervariasi (Gambar 1).

Manfaat desikasi terhadap perkecambahan telah banyak dilaporkan, sebagaimana hasil penelitian pada benih sorgum (De Almeida et al., 2014). Desikasi juga memberi manfaat bagi perbaikan perkecambahan benih kacang bambara ini, meskipun belum mampu mematahkan dormansi tersebut. Pengamatan saat 30 HST menunjukkan benih segar hanya memiliki daya tumbuh $48.9 \%$ (D0) sedangkan saat benih dikeringkan hingga 12.1\% (D4) daya tumbuhnya meningkat menjadi 78.9\% (Gambar 1). Hasil uji di lapangan ini menunjukkan bahwa benih kacang bambara memiliki dormansi primer karena dormansi telah ada saat benih dipanen dari tanaman induknya dan bukan terinduksi oleh faktor lingkungan yang dapat mempengaruhinya setelah panen.

Kecepatan perkecambahan benih berbeda antar benih dari tingkat desikasi yang berbeda. Berdasarkan grafik yang menunjukkan laju perkecambahan (Gambar 1), benih dapat dibagi dalam tiga kelompok. Kelompok tersebut adalah benih dengan tingkat dormansi sangat kuat (D0, KA 54.7\% dan D1, KA 44.4\%), benih dengan tingkat dormansi sedang (D2, KA 18.0\%), dan benih dengan tingkat dormansi ringan (D3, KA 15.4\% dan D4, KA12.1\%).

\section{Pengaruh Desikasi terhadap Permeabilitas Benih}

Perbedaan tingkat desikasi mengakibatkan perbedaan kemampuan benihuntukberimbibisi.Gambar 2 menunjukkan ada tiga kelompok benih dengan kemampuan imbibisi yang berbeda. Benih D1 (KA 44.4\%) merupakan benih dengan laju imbibisi cepat, benih D2 (KA 18.0\%) merupakan benih dengan laju imbibisi sedang, dan benih D0, D3, dan D4 (KA 54.7\%, 15.4\%, dan 12.1\%) merupakan benih dengan laju imbibisi lambat. Kadar air yang rendah pada benih D3 (KA 15.4\%) dan D4 (KA 12.1\%) tidak menyebabkan benih berimbibisi lebih cepat dibanding benih D1 (KA 44.4\%). Kondisi tersebut menunjukkan adanya perbedaan tingkat permeabilitas benih yang bukan disebabkan oleh perbedaan potensial air.

Air dapat masuk ke dalam benih melalui berbagai jalan, seperti hilum, mikropil, raphe, maupun testa (De Souza dan Marcos-Filho, 2001). Benih kacang bambara yang belum kering (D1 dan D2) berimbibisi dengan baik pada perlakuan perendaman $\mathrm{KNO}_{3}$ tanpa skarifikasi (P3) maupun dengan skarifikasi (P4) (Tabel 1). Sebaliknya, pada benih kering (D3 dan D4), imbibisi $\mathrm{KNO}_{3}$ baru dapat berlangsung dengan baik setelah benih mengalami penipisan pada testa akibat skarifikasi (P4) (Tabel 1). Hasil ini menunjukkan adanya perubahan permeabilitas pada testa akibat desikasi. Desikasi menyebabkan testa berubah dari kondisi permeabel pada benih D1 (KA 44.4\%) dan D2 (KA 18.0\%) menjadi kurang permeabel pada benih D3 (KA $15.4 \%)$ dan D4 (12.1\%).

Benih segar (D0) juga memiliki laju imbibisi sangat rendah sebagaimana benih D3 (KA 15.4\%) dan D4 (KA $12.1 \%)$, meskipun penyebab rendahnya permeabilitas antara benih segar dengan benih kering ada perbedaan. Hambatan permeabilitas pada benih kering D3 dan D4 dapat diatasi

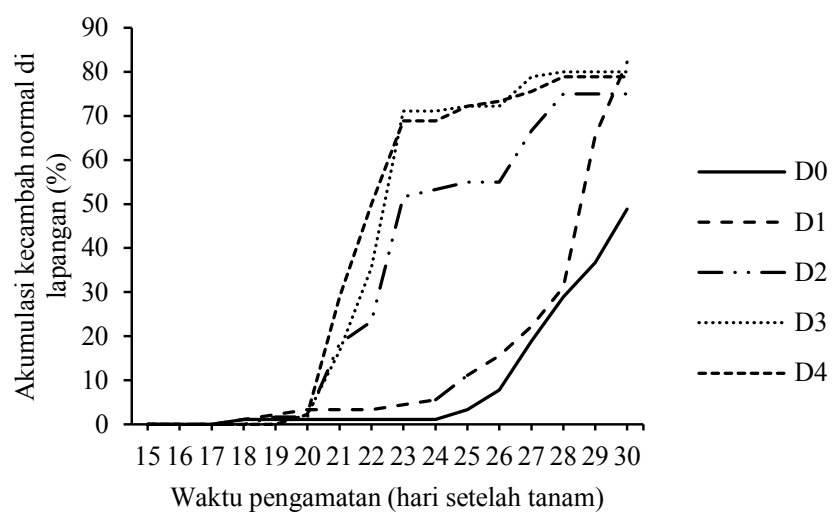

Gambar 1. Akumulasi kecambah normal di lapangan pada berbagai tingkat desikasi benih kacang bambara. D0 = benih segar tanpa desikasi (kadar air 54.7\%); D1 = desikasi hingga kadar air 44.4\%; D2 = kadar air 18.0\%; D3 $=$ kadar air $15.4 \%$; D4 = kadar air 12.1\% 


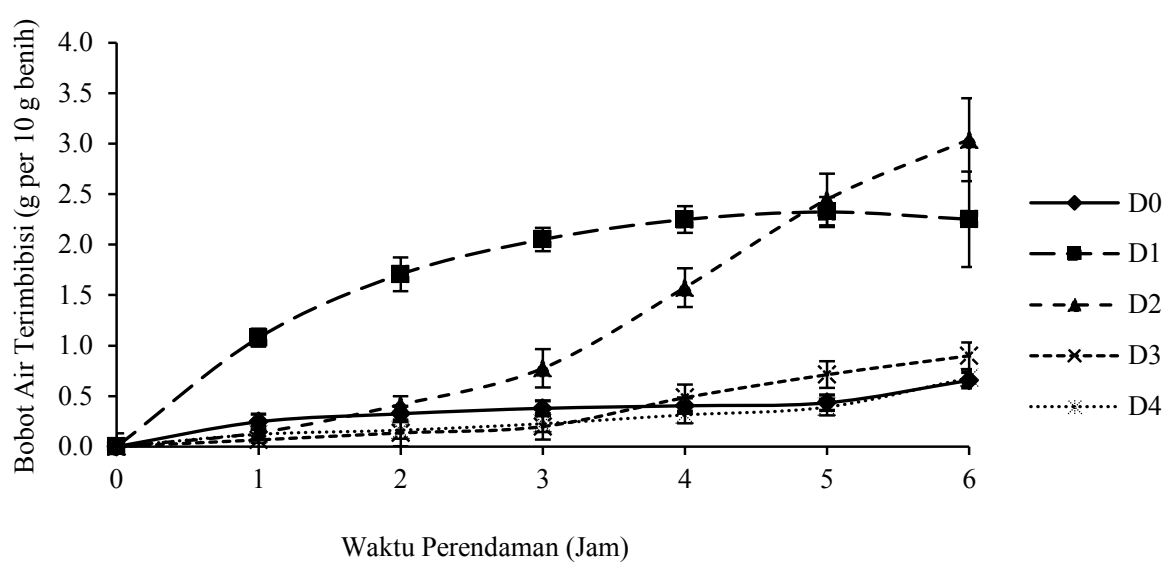

Gambar 2. Laju imbibisi benih kacang bambara lanras Sumedang pada berbagai tingkat desikasi. D0 = benih segar tanpa desikasi (kadar air 54.7\%); D1 = desikasi hingga kadar air 44.4\%; D2 = kadar air 18.0\%; D3 = kadar air 15.4\%; D4 = kadar air 12.1\%

dengan skarifikasi, namun skarifikasi pada benih segar (D0) tidak mampu meningkatkan kemampuan benih berimbibisi (Tabel 1). Perbedaan respon tersebut menunjukkan hambatan imbibisi pada benih D0 tidak hanya terdapat pada testa. Desikasi dari benih D1 (KA 44.4\%) menuju D4 (KA 12.1\%) menurunkan permeabilitas, sementara desikasi dari benih D0 (KA 54.7\%) menuju D1 (KA 44.4\%) meningkatkan permeabilitas (Gambar 2, Tabel 1). Berdasarkan hasil telaah dari berbagai penelitian, De Souza dan Marcos-Filho (2001) mengemukakan bahwa impermeabilitas benih telah mulai terjadi pada saat akhir periode reproduksi dan ditandai dengan perubahan warna testa yang semakin gelap. Kondisi serupa juga ditemukan pada benih kacang bambara segar (D0) yang cenderung impermeabel (Gambar 2, Tabel 1).

Pemanasan saat desikasi dapat menyebabkan benih menjadi permeabel. Benih Pisum sativum L. yang masih segar memiliki sel-sel palisade yang tersusun sangat dekat dan rapat sehingga mengakibatkan benih impermeabel. Pemanasan $50{ }^{\circ} \mathrm{C}$ dapat menyebabkan kerusakan pada sejumlah lapisan sel-sel tersebut yang menyebabkan adanya jarak antar sel. Selain itu, juga terjadi lisis pada sejumlah sel dan akhirnya menyebabkan munculnya permeabilitas saat benih mulai dikeringkan (Shereena dan Salim, 2006). Hal yang sama diduga terjadi pula pada benih kacang bambara pada awal desikasi, sehingga terjadi perubahan dari benih segar yang impermeabel (D0, KA 54.7\%) menjadi benih yang permeabel pada awal proses desikasi (D1, KA 44.4\%) (Gambar 2, Tabel 1).

Perubahan permeabilitas dari D1 (KA 44.4\%) menuju D4 (KA 12.1\%) selanjutnya berangsur berkurang (Gambar 2, Tabel 1). Penelitian oleh Shereena dan Salim (2006) pada benih Pisum sativum L. bahkan menunjukkan benih dapat menjadi sangat impermeabel sebagai benih keras yang irreversible bila mengalami pengeringan hingga KA 7.9\%. Hal ini menunjukkan adanya keterkaitan erat antara desikasi dengan integritas testa yang perlu diperhatikan.

\section{Hubungan Permeabilitas, Faktor Fisiologi, dan Perkecambahan}

Testa seringkali menghambat perkecambahan. Proses imbibisi merupakan proses paling awal dalam metabolisme perkecambahan. Benih yang mampu berimbibisi dengan baik diharapkan dapat berkecambah dengan baik, sebaliknya benih yang mengalami hambatan pada proses imbibisi dikhawatirkan terkendala dalam perkecambahannya. Debeaujon et al. (2000) mengemukakan bahwa benih mutan testa Arabidopsis memiliki perkecambahan lebih baik

Tabel 1. Pengaruh desikasi dan perlakuan pematahan dormansi terhadap kadar air benih (\%) kacang bambara lanras Sumedang

\begin{tabular}{llllllc}
\hline \multirow{2}{*}{ Pematahan dormansi } & \multicolumn{9}{c}{ Tingkat desikasi } \\
\cline { 2 - 7 } & D0 & D1 & D2 & D3 & D4 & Rata-rata \\
\hline Kontrol (P1) & $54.7 \mathrm{ab}$ & $44.4 \mathrm{~b}$ & $18.0 \mathrm{~b}$ & $15.4 \mathrm{c}$ & $12.1 \mathrm{~b}$ & 28.9 \\
Skarifikasi (P2) & $53.5 \mathrm{~b}$ & $50.6 \mathrm{ab}$ & $16.6 \mathrm{~b}$ & $16.1 \mathrm{c}$ & $13.4 \mathrm{~b}$ & 31.0 \\
$\mathrm{KNO}_{3}(\mathrm{P} 3)$ & $59.1 \mathrm{a}$ & $53.4 \mathrm{a}$ & $28.8 \mathrm{a}$ & $22.2 \mathrm{~b}$ & $18.5 \mathrm{~b}$ & 37.7 \\
Skarifikasi $+\mathrm{KNO}_{3}(\mathrm{P} 4)$ & $56.4 \mathrm{ab}$ & $54.2 \mathrm{a}$ & $30.7 \mathrm{a}$ & $35.0 \mathrm{a}$ & $28.3 \mathrm{a}$ & 40.9 \\
\hline Rata-rata & $55.9 \mathrm{~A}$ & $50.6 \mathrm{~B}$ & $24.2 \mathrm{C}$ & $22.2 \mathrm{C}$ & $18.0 \mathrm{D}$ & \\
\hline
\end{tabular}

Keterangan: D0 = benih segar (kadar air (KA) 54.7\%); D1 = desikasi hingga KA 44.4\%; D2 = KA 18.0\%; D3 = KA 15.4\%; D4 = KA $12.1 \%$. Angka pada kolom yang sama diikuti huruf kecil yang sama dan angka pada baris yang sama diikuti huruf kapital yang sama tidak berbeda nyata pada DMRT $\alpha=0.05$. Koefisien keragaman $=8.79$ 
dibandingkan tipe liarnya. Hal ini dijelaskan sebagai efek dari permeabilitas yang lebih baik untuk masuknya stimulan perkecambahan (seperti air dan oksigen) maupun keluarnya inhibitor endogen (seperti ABA) pada benih mutan tersebut. Hilangnya dormansi pada benih Arabidopsis akibat mutasi pada testa menjelaskan peran testa dalam mekanisme dormansi dan perkecambahan. Hasil penelitian Miya dan Modi (2017) pada benih kacang bambara menunjukkan adanya hambatan perkecambahan oleh lapisan testa dan perlakuan skarifikasi, baik secara mekanik maupun kimia mampu meningkatkan daya tumbuhnya. Pada kenyataannya, penelitian kali ini menunjukkan benih dengan permeabilitas tinggi (D1, KA 44.4\%) memiliki laju perkecambahan yang lebih lambat dibanding benih dengan permeabilitas rendah (D3 dan D4, KA 15.4\% dan 12.1\%) (Gambar 1). Hasil ini mengindikasikan bahwa proses desikasi dari D1 menuju D3 memiliki peran penting dalam perubahan fisiologi perkecambahan, sehingga terjadi peningkatan laju perkecambahan pada benih D3, meskipun permeabilitasnya semakin rendah dibanding benih D1. Faktor fisiologi yang sering mempengaruhi perkecambahan dan dormansi adalah keseimbangan giberelin (GA) dan asam absisat (ABA). Dormansi fisiologi dapat disebabkan oleh hambatan inhibitor yang terlalu kuat atau stimulasi hormon perkecambahan yang kurang.

\section{Pengaruh Desikasi terhadap Fitohormon}

Desikasi benih berpengaruh nyata terhadap daya tumbuh (Tabel 2). Diantara benih yang telah mengalami desikasi, benih D1 memiliki daya tumbuh paling rendah (Tabel 2), laju perkecambahan paling lambat (Gambar 1), dan rasio GA/ABA paling kecil (Gambar 3). Rasio GA/ ABA yang sangat rendah pada D1 memegang peran utama dalam pengendalian dormansi benih masak fisiologi yang baru mengalami sedikit desikasi ini (D1, KA 44.4\%) karena pada kondisi tersebut proses imbibisi sebenarnya tidak ada hambatan (Gambar 2, Tabel 1).

Perubahan fitohormon merupakan salah satu masalah fisiologi yang banyak dipelajari untuk menjelaskan kondisi benih siap berkecambah atau dorman. Pengukuran rasio GA/ABA digunakan untuk menjelaskan fenomena perkecambahan dan dormansi pada benih selama proses desikasi tersebut. Berdasarkan Gambar 3, rasio GA/ABA dapat dikelompokkan menjadi tiga kelompok, yaitu benih dengan rasio GA/ABA tinggi (D0, D3, dan D4), benih dengan rasio GA/ABA sedang (D2), dan benih dengan rasio GA/ABA rendah (D1) (Gambar 3). Hasil ini dapat menjelaskan perkecambahan benih D3 dan D4 yang lebih baik dibanding benih D1 (Gambar 1, Tabel 2), meskipun permeabilitas pada benih D3 dan D4 jauh lebih rendah dibandingkan D1 (Gambar 2). Daya tumbuh benih yang telah kering, D3 (KA 15.4\%) dan D4 (KA 12.1\%) sebesar $71.1 \%$ dan $70.6 \%$ nyata lebih tinggi dibanding daya tumbuh benih D1 (KA 44.4\%) yang baru mulai dikeringkan (62.1\%) (Tabel 2). Sementara itu, kuatnya dormansi yang terjadi pada benih segar yang belum mengalami desikasi (D0) terkait fitohormon dan impermeabilitasnya masih menjadi materi yang perlu didiskusikan.

\section{Pengaruh Skarifikasi dan Perendaman dalam $\mathrm{KNO}_{3}$ terhadap Perkecambahan}

Benih menunjukkan peningkatan daya tumbuh seiring dengan desikasi yang dialaminya hingga kadar air 12.1\%, namun dormansi belum terpatahkan. Upaya perbaikan perkecambahan melalui skarifikasi dan perendaman dalam $\mathrm{KNO}_{3}$ pada benih tersebut tidak menunjukkan hasil positif. Pengaruh perlakuan pematahan dormansi terhadap daya tumbuh di lapangan berbeda secara spesifik pada setiap tingkat desikasi (Tabel 2). Secara umum, daya tumbuh benih tanpa perlakuan (kontrol) memberikan hasil terbaik, kecuali pada perlakuan benih segar tanpa desikasi. Pada benih yang belum mengalami desikasi (D0), perlakuan perendaman dalam $\mathrm{KNO}_{3}$ mampu meningkatkan daya tumbuh dari 48.9\% menjadi $68.9 \%$ (Tabel 2). Meskipun pada percobaan ini tidak dilakukan pengamatan untuk membandingkan kandungan ABA sebelum dan setelah perlakuan $\mathrm{KNO}_{3}$, namun Liu et al. (2009) mengemukakan bahwa NO berperan dalam katabolisme ABA pada tahap awal imbibisi. Meskipun perlakuan perendaman dalam $\mathrm{KNO}_{3}$ dapat menstimulir daya tumbuh benih D0 menjadi lebih baik, namun belum mampu

Tabel 2. Pengaruh desikasi dan perlakuan pematahan dormansi terhadap daya tumbuh (\%) pada benih kacang bambara lanras Sumedang

\begin{tabular}{|c|c|c|c|c|c|c|}
\hline \multirow{2}{*}{ Pematahan dormansi } & \multicolumn{5}{|c|}{ Tingkat desikasi } & \multirow[b]{2}{*}{ Rata-rata } \\
\hline & D0 & D1 & D2 & D3 & D4 & \\
\hline & \multicolumn{6}{|c|}{ 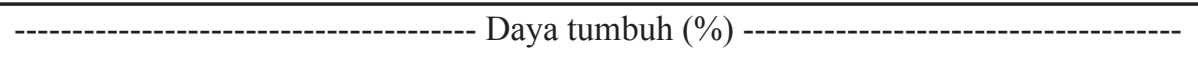 } \\
\hline Kontrol (P1) & $48.9 b$ & $82.2 \mathrm{a}$ & $75.0 \mathrm{a}$ & $80.0 \mathrm{a}$ & $78.9 \mathrm{a}$ & 72.9 \\
\hline Skarifikasi (P2) & $36.7 \mathrm{bc}$ & $51.7 \mathrm{~b}$ & $61.7 \mathrm{ab}$ & $65.6 b$ & $64.4 \mathrm{a}$ & 55.9 \\
\hline $\mathrm{KNO}_{3}(\mathrm{P} 3)$ & $68.9 \mathrm{a}$ & $75.6 \mathrm{a}$ & $54.4 \mathrm{~b}$ & $64.4 b$ & $72.2 \mathrm{a}$ & 67.1 \\
\hline Skarifikasi $+\mathrm{KNO}_{3}(\mathrm{P} 4)$ & $21.1 \mathrm{c}$ & $35.6 b$ & $67.8 \mathrm{ab}$ & $74.5 \mathrm{ab}$ & $66.7 \mathrm{a}$ & 53.1 \\
\hline Rata-rata & $43.9 \mathrm{C}$ & $62.1 \mathrm{~B}$ & $64.0 \mathrm{AB}$ & $71.1 \mathrm{~A}$ & $70.6 \mathrm{~A}$ & \\
\hline
\end{tabular}

Keterangan: D0 = benih segar (kadar air (KA) 54.7\%); D1 = desikasi hingga KA 44.4\%; D2 = KA 18.0\%; D3 = KA 15.4\%; D4 = KA $12.1 \%$. Angka pada kolom yang sama diikuti huruf kecil yang sama dan angka pada baris yang sama diikuti huruf kapital yang sama tidak berbeda nyata pada DMRT $\alpha=0.05$. Koefisien keragaman $=14.32$ 


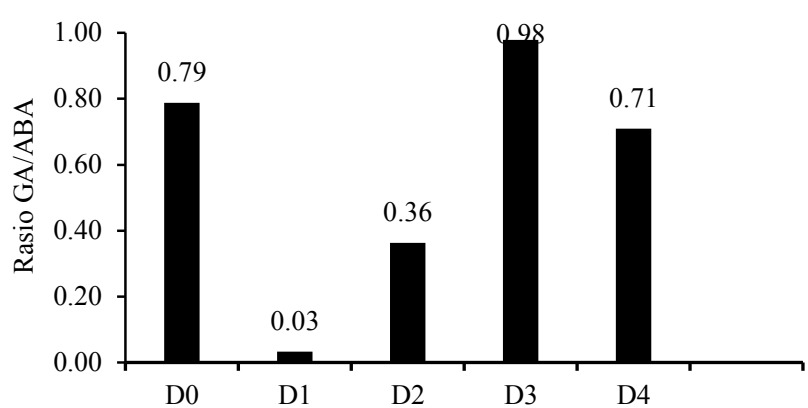

Gambar 3. Rasio GA/ABA benih kacang bambara lanras Sumedang dari beberapa perlakuan tingkat desikasi. D0 = benih segar tanpa desikasi (kadar air 54.7\%); D1 = desikasi hingga kadar air 44.4\%; D2 = kadar air 18.0\%; D3 = kadar air 15.4\%; D4 = kadar air $12.1 \%$. Rasio GA/ABA dihitung setelah diperoleh nilai GA dan ABA dari 3 ulangan

mendorong benih untuk muncul di lapangan pada 10 hari sebagaimana perkecambahan pada benih tanpa dormansi.

Miya dan Modi (2017) mengemukakan bahwa skarifikasi mampu meningkatkan daya tumbuh benih kacang bambara meskipun menurunkan vigornya di lapangan. Pada penelitian ini, benih yang telah mengalami desikasi secara umum memiliki daya tumbuh tertinggi pada perlakuan kontrol. Wang et al. (2011) mengemukakan skarifikasi menggunakan kertas amplas merupakan perlakuan yang paling aman untuk pematahan dormansi fisik, sebagaimana dibuktikan pada lima spesies liar Vigna. Meskipun demikian, perlakuan skarifikasi menggunakan amplas pada penelitian kali ini justru memberikan pengaruh negatif (Tabel 2). Mempercepat laju imbibisi melalui perlakuan skarifikasi dengan harapan mempercepat perkecambahan, ternyata bukan perlakuan yang tepat bagi benih kacang bambara yang baru dipanen. Upaya pematahan dormansi melalui perendaman dalam $\mathrm{KNO}_{3}$ pada benih kacang bambara yang baru dipanen pada penelitian kali ini juga tidak berpengaruh positif (Tabel 2). Upaya menstimulir produksi $\mathrm{GA}_{3}$ endogen untuk meningkatkan rasio GA/ABA perlu dipelajari untuk keberhasilan pematahan dormansi benih kacang bambara. Modifikasi pada metode pengeringan untuk mempercepat peningkatan rasio GA/ABA dengan menjaga testa tetap permeabel perlu dipelajari lebih lanjut, sehingga proses pengeringan tidak hanya menghasilkan benih yang siap simpan namun juga siap tanam.

\section{KESIMPULAN}

Benih kacang bambara memiliki dormansi primer. Desikasi berpengaruh terhadap dormansi benih. Desikasi meningkatkan daya tumbuh benih dari $43.9 \%$ pada benih segar menjadi sekitar 70\% pada benih kering dengan kadar air $12-15 \%$ (pada pengamatan 30 HST). Peningkatan daya tumbuh terjadi seiring dengan peningkatan rasio GA/ABA pada desikasi dari KA 44.4\% menjadi $12.1 \%$, meskipun pada tahap desikasi tersebut permeabilitas testa semakin berkurang. Desikasi hingga KA 12.1\% belum mampu mematahkan dormansi, namun informasi dari hasil penelitian ini menjadi dasar kuat adanya peluang pematahan dormansi melalui modifikasi metode pengeringan. Metode pengeringan perlu diarahkan pada upaya mempercepat peningkatan rasio $\mathrm{GA} / \mathrm{ABA}$ dengan menjaga testa tetap permeabel.

\section{DAFTAR PUSTAKA}

Abu-Salem, F.M., A.A. Abou-Arab. 2011. Effect of supplementation of bambara groundnut (Vigna subterranea L.) flour on the quality of biscuits. Afr. J. Food Sci. 5:376-383.

Adelanwa, M.A., M.I.A., M.S. Mohammed, A.E. Esson. 2017. Variation mineral compositions of some Bambara groundnut (Vigna subterranea (L.) Verdc.) accessions. Research in Science and Technology 9:06-09.

Adhi, R.K., S. Wahyudi. 2018. Pertumbuhan dan hasil kacang bogor (Vigna subterranea (L.) Verdc.) varietas lokal Lembang di Kalimantan Selatan. Ziraa'ah 43:192-197.

Bakti, N.H., D.P. Waluyo, B. Kuswanto, D. Saptadi. 2018. Penampilan hasil enam galur harapan kacang bogor (Vigna subterranea (L.) Verdc.). Jurnal Produksi Tanaman 6:1058-1065.

De Almeida, T.T., S.D.V.F. da Rosa, J.K Oliveira, A.S. Oliveira, A.A. da Silva, D.S. Pereir. 2014. Influence of tannin on sorghum seed germination. Afr. J. Food Sci. Technol. 5:136-142.

De Souza, F.H.D., J. Marcos-Filho. 2001. The seed coat as a modulator of seed-environment relationships in Fabaceae. Rev. Bras. Bot. 24:365-375.

Debeaujon, I., K.M. Le'on-Kloosterziel, M. Koornneef. 2000. Influence of the testa on seed dormancy, germination, and longevity in Arabidopsis. Plant Physiol. 122:403-413.

[ISTA] International Seed Testing Association. 2014. International Rules for Seed Testing. Edition 2014. International Seed Testing Association. Zurich. Switzerland.

Jaganathan, G.K., D. Song W. Liu, Y. Han, B. Liu . 2017. Relationship between seed moisture content and acquisition of impermeability in Nelumbo nucifera (Nelumbonaceae). Acta Bot. Bras. 31:639644.

Liu, Y., L. Shi, N. Ye, R. Liu, W. Jia, J. Zhang. 2009. Nitric oxide-induced rapid decrease of abscisic acid concentration is required in breaking seed dormancy in Arabidopsis. New Phytol. 183:1030-1042. 
Manggung. R.E.R., A. Qadir. S. Ilyas. 2016. Fenologi, morfologi, dan hasil empat aksesi kacang bambara (Vigna subterranea (L.) Verdc.). J. Agron. Indonesia 44:47-54.

Mayes, S., W.K. Ho, H.H. Chai, X. Gao, A.C. Kundy, K.I. Mateva, M. Zahrulakmal, M.K.I.M. Hahiree, P. Kendabie, L.C.S. Licea, F. Massawe, T. Mabhaudhi, A.T. Modi, J.N. Berchie, S. Amoah. 2019. Bambara groundnut: An exemplar underutilised legume for resilience under climate change. Planta 250:803820 .

Miya, S.P., A.T. Modi. 2017. Overcoming the physical seed dormancy in bambara groundnut (Vigna subterranea L.) by scarification: A seed quality study. J. Agric. Sci. Tech. B 7:13-24.

Mizuno, Y., U. Yamanouchi, T. Hoshino, Y. Nonoue, K. Nagata, S. Fukuoka, T. Ando, M. Yano, K. Sugimoto. 2018. Genetic dissection of pre-harvest sprouting resistance in an upland rice cultivar. J. Breeding Sci. 68:200-209.

Olaerts, H., C.M. Courtin. 2018. Impact of preharvest sprouting on endogenous hydrolases and technological quality of wheat and bread: A review. Compreh. Rev. Food Sci. Food Safety 17:698-713.
Oba, G.C., A.L. A.L.D. Goneli, T.E. Masetto, C.P. Hartmann Filho, K.L.S.. Michels, J.P.C. Ávila. 2019. Artificial drying of safflower seeds at different air temperatures: effect on the physiological potential of freshly harvested and stored seeds. J. Seed Sci. 41:397-406.

Olaleye, A.A., E.I. Adeyeye, A.J. Adesina. 2013. Chemical composition of bambara groundnut (Vigna subterranea L. Verdc) seed parts. Bangladesh J. Sci. Ind. Res. 48:167-178.

Ran, X., H. Wan, J. Li, Y. Liang, J. Xu. 2015. An investigation of the relationship between lignin content and seed coat traits in yellow-seeded Brassica napus L. Acad. J. Agric. Research 3:001-008.

Shereena, J., N. Salim. 2006. Influence of seed moisture content and leakage on germination and viability in Pisum sativum L. seeds. Internat. J. Bot. 2:277-430.

Wang, Y.R., J. Hanson, Y.W. Mariam. 2011. Breaking hard seed dormancy in diverse accession of five wild Vigna species by hot water and mechanical scarification. Seed Sci. Technol. 39:12-20. 